\title{
Endoscopic management of recurrent pancreatitis
}

\author{
Glen A. Lehman
}

Department of Medicine, Division of Gastroenterology and Hepatology, Indiana University Medical Center, Indianapolis, IN, USA

Abstract
$\begin{aligned} & \text { Endoscopic therapy is a well-established, valuable alternative to surgery for the treatment of } \\ & \text { a variety of biliary tract diseases. Applications of similar techniques to the pancreas continue } \\ & \text { to develop. Encouraged by the recognition of the relative safety of ERCP and endoscopic } \\ & \text { sphincterotomy (ES) for gallstone pancreatitis, endoscopic therapy is now being applied in } \\ & \text { the setting of acute pancreatitis of other etiologies, chronic pancreatitis, complications of } \\ & \text { acute or chronic pancreatitis, and pancreas divisum. }\end{aligned}$
Key words
Endoscopic sphincterotomy, pancreas divisum, recurrent pancreatitis

\section{Introduction}

Endoscopic therapy is a well-established, valuable alternative to surgery for the treatment of a variety of biliary tract diseases. Applications of similar techniques to the pancreas continue to develop. Progress in this area has been somewhat slow because of the concern for procedure-related complications. Encouraged by the recognition of the relative safety of ERCP and endoscopic sphincterotomy (ES) for gallstone pancreatitis, endoscopic therapy is now being applied in the setting of acute pancreatitis of other etiologies, chronic pancreatitis, complications of acute or chronic pancreatitis, and pancreas divisum [Table 1]. Since one third of "acute" pancreatitis patients already have chronic pancreatitis by more detailed evaluation, this approach applies to both groups. While the underlying cause of the pancreatitis (ethanol, high triglycerides etc) should be corrected if possible, most endoscopic therapies apply to all etiologies whether correctable or not. Pancreatic techniques are more technically demanding as noted by the Schutz Classification.

\section{Management of Recurrent Pancreatitis}

Management of recurrent pancreatitis can be categorized

\begin{tabular}{|l|c|}
\hline \multicolumn{2}{|c|}{ Access this article online } \\
\hline \multirow{2}{*}{$\begin{array}{l}\text { Website: } \\
\text { www.jdeonline.in }\end{array}$} & Quick Response Code \\
\hline \multirow{2}{*}{$\begin{array}{l}\text { DOI: } \\
\text { 10.4103/0976-5042.95034 }\end{array}$} & (1) \\
\hline
\end{tabular}

according to noninvasive imaging and serologic testing. 1. Specific findings such as biliary or pancreas stones (for which endoscopic, surgical or other therapy is appropriate). 2. Nonspecific abnormality such as ductal dilation. 3. Normal. The latter two groups are better managed at referral center with a full armamentarium of techniques available (eg. Manometry, ductoscopy, stentings, etc). Fischer reported the endoscopic finding on a large series of acute and acute recurrent idiopathic pancreatitis [Table 2]. ${ }^{[1]}$

Sphincter of Oddi Dysfunction (SOD) was the most common finding. Pancreatic basal sphincter pressure was abnormal in $57 \%$ of 888 manometrically studied patients while $36 \%$ had biliary sphincter basal pressure $\geq 40 \mathrm{mmHg}$. Biliary sphincterotomy alone improves $50-70 \%$ of such patients while combined pancreatobiliary is more efficacious. Residual pancreatic duct sphincter hypertension may account for the lack of improvement following biliary ES alone. Thorough evaluation of such patents includes bi-ductal manometry (both initially and if repeat study is needed). Recent studies show that rectal NSAIDS given immediately after ERCP decrease post ERCP pancreatitis by $50 \%{ }^{[2]}$ Outcome studies are limited but SOD therapy gives pain/pancreatitis resolution in approximately $50 \%$ of chronic pancreatitis patients and $80 \%$ of patients without evidence of chronic pancreatitis.

Chronic pancreatitis changes were the $2^{\text {nd }}$ most common finding (35\%) in the Fischer series. ${ }^{[1]}$ Management of pancreatic ductal strictures, pseudocysts, and stones is similar no matter what the etiology of pancreatitis. Simple management of pancreatic duct stricture is dilation and plastic stents. Duration and diameter of stenting needed to give stricture long-term patency is only partially known. Longer and bigger seems 


\begin{tabular}{|c|c|}
\hline Clinical condition & Endoscopic therapy \\
\hline $\begin{array}{l}\text { Recurrent or chronic } \\
\text { pancreatitis, smoldering } \\
\text { pancreatitis }\end{array}$ & $\begin{array}{l}\text { Endoscopic sphincterotomy (bile duct and/ } \\
\text { or pancreatic), stricture dilation, stone } \\
\text { extraction } \pm \text { extracorporeal shockwave } \\
\text { lithotripsy, bile duct and/or pancreatic duct } \\
\text { stents }\end{array}$ \\
\hline $\begin{array}{l}\text { Pancreatic pseudocysts, } \\
\text { PD disruption/ascites }\end{array}$ & $\begin{array}{l}\text { Cystoenterostomy, transpapillary stenting } \\
( \pm \text { EUS assistance) }\end{array}$ \\
\hline Pancreas divisum & $\begin{array}{l}\text { Minor papilla endoscopic sphincterotomy, } \\
\text { stent and/or dilation }\end{array}$ \\
\hline Pancreatic necrosis & Necrosectomy \\
\hline
\end{tabular}

\begin{tabular}{lcc}
\hline Table 2: Post-procedure diagnosis* & & \\
\hline Clinical condition & $\begin{array}{c}\text { Number of } \\
\text { patients }\end{array}$ & $\begin{array}{c}\text { Percent } \\
\text { of 1,241 }\end{array}$ \\
\hline Sphincter of oddi dysfunction & 501 & 40.4 \\
Pancreas divisum & 233 & 18.8 \\
Periampullary diverticulum & 75 & 6.0 \\
Intraductal mucinous tumors & 52 & 4.2 \\
Choledocholithiasis / ductal sludge & 19 & 1.5 \\
Cholelithiasis / gallbladder sludge & 19 & 1.5 \\
Choledochal cysts & 10 & 0.8
\end{tabular}

*Some of the patients had more than one diagnosis

better but this involves multiple endoscopic sessions and may require expandable metal stents (fully covered) to achieve full luminal patency. Further studies comparing plastic stents to fully coated metal stents are awaited.

Cahen ${ }^{[3]}$ reported that surgical bypass treatment of head main duct strictures gave superior pain relief at 5 years than endoscopic (incomplete) therapy. Thorough risk-benefit discussion should take place before initiating endoscopic or surgical treatment. Pseudocysts, stones and necrosis will be left to more specific chronic pancreatitis sessions. ${ }^{\left[{ }^{[4]}\right.}$

Pancreas divisum is a congenital anomaly which causes relative obstruction to outflow of pancreatic juice via an always small diameter minor papilla. Recent studies show an association between genetic abnormalities (PRSS1, SPINK1, and cystic fibrosis) and pancreas divisum. ${ }^{[5,6]}$

Similar to sphincter of Oddi dysfunction of the major papilla, approximately $80 \%$ of pancreas divisum patients without chronic pancreatitis will have pancreatitis resolution/ improvement for 2-5 years after endoscopic sphincterotomy. Some studies report similar efficacy from only placement of 5-7 Fr stent $\chi$ 3-6 months. We find that such stent therapy causes ductal strictures upstream to the minor papilla and is strongly discouraged.

Acute recurrent pancreatitis with associated LFT abnormality raises concern for biliary etiology. Noninvasive imaging (US, EUS, MRCP) will usually clarify the biliary (or not) etiology. This is an important categorization point as biliary stone patients have low risk from biliary sphincterotomy, whereas other etiologies (especially sphincter of Oddi dysfunction) are high risk for post ERCP complications. When ductal biliary stones are suspected but not found, factors to weigh in the final treatment plan are 1) current/past gall bladder stones; 2) lacerated papilla as from stone passage; 3) pancreatogram (preferably limited extent) evidence of an etiology such as mucus in duct; 4) sphincter manometry availability; 5) biliary sphincterotomy alone vs. additional pancreatic prophylactic stent. These factors are especially important in smaller hospitals without manometry or pancreatic stenting availability.

\section{Conclusion}

Endoscopic therapy of pancreatic disease is an evolving arena. Selection of appropriate candidates for the various treatment modalities appears important for optimal results of therapy. Controlled studies with long term follow up are awaited.

\section{References}

1. Fischer M, Hassan A, Sipe BW, Fogel EL, McHenry L, Sherman S, et al. Endoscopic retrograde cholangiopancreatography and manometry findings in 1,241 idiopathic pancreatitis patients. Pancreatology 2010;10:444-52.

2. Elmunzer BJ, Scheiman JM, Lehman GA, Chak A, Mosler P, Higgins PDR, et al. A randomized trial of rectal indomethacin to prevent post-ERCP pancreatitis. N Engl J Med 2012;366:1414-22.

3. Cahen DL, Gouma DJ, Laramee P, Nio Y, Rauws EA, Boermeester MA, et al. Long-term outcomes of endoscopic vs. surgical drainage of the pancreatic duct in patients with chronic pancreatitis. Gastroenterology 2011;141:1690-5.

4. Choi EK, Lehman GA. Update on endoscopic management of main pancreatic duct stones in chronic calcific pancreatitis. Korean J Intern Med 2012;27:20-9.

5. Bertin C, Pelletier AL, Vullierme MP, Bienvenu T, Rebours V, Hentic $\mathrm{O}$, et al. Pancreas divisum is not a cause of pancreatitis by itself but acts as a partner of genetic mutations. Am J Gastroenterol 2012;107:311-7.

6. Choudari, CP, Imperiale TF, Sherman S, Fogel E, Lehman GA. Risk of pancreatitis with mutation of the cystic fibrosis gene. Am J Gastroenterol 2004;99:1358-63.

How to cite this article: Lehman GA. Endoscopic management of recurrent pancreatitis. J Dig Endosc 2012;3:56-7.

Source of Support: Nil, Conflict of Interest: None declared. 